\section{Evaluation of Aluminum Tolerance and Nutrient Uptake of 50 Centipedegrass Accessions and Cultivars}

\author{
Jun Yan \\ Department of Horticulture, Nanjing Agricultural University, Nanjing \\ 210095, P.R. China \\ Jingbo Chen, Tingting Zhang, and Jianxiu Liu ${ }^{1}$ \\ Institute of Botany, Jiangsu Province, Chinese Academy of Science, Nanjing \\ 210014, P.R. China

\section{Haibo Liu ${ }^{1}$ \\ Department of Horticulture, Clemson University, 253 Poole Agriculture Center, P.O. Box 340375, Clemson, SC 29634-0375}

Additional index words. aluminum toxicity, acid soils, turfgrass, turfgrass nutrition, $\mathrm{Al}$ resistance, calcium, potassium, phosphorus, magnesium

\begin{abstract}
Centipedegrass [Eremochloa ophiuroides (Munro) Hack] is a native grass of China, and information on soil adaptation ranges, including acid soils, among centipedegrass cultivars is limited. Therefore, objectives of this study were 1) to conduct a preliminary evaluation of relative aluminum tolerance of 48 centipedegrass accessions plus a cultivar, TifBlair, and a common centipedegrass under aluminum (AI) stress (0 and $1500 \mu \mathrm{M} \mathrm{Al}$ ) by using a solution culture method; and 2) to determine Al effects on nutrient uptake between resistant-group and sensitive-group accessions among the 50 accessions and cultivars. Differences were found among accessions and cultivars, and the $\mathrm{CV}$ of relative root weight, relative shoot weight, and relative total weight were $39.9 \%$, $32.9 \%$, and $33.6 \%$, respectively. After growing 28 days in an acid subsoil, the resistantgroup accessions showed much better growth than the sensitive-group accessions. The Al concentrations in roots and shoots of the two groups of accessions were increased under $\mathrm{Al}$ treatment, but most absorbed $\mathrm{Al}$ remained in roots with greater $\mathrm{Al}$ absorption among the sensitive group compared with the resistant group. The concentrations of phosphorus $(\mathrm{P})$, magnesium (Mg), calcium (Ca), and potassium $(\mathrm{K})$ in the two groups were reduced under Al stress with reductions of $59.3 \%, 54.8 \%, 47.9 \%$, and $41.3 \%$ in shoots and reductions of $8.70 \%, 52.5 \%, 43.2 \%$, and $34.4 \%$ in roots, respectively. Under Al stress, differences in $\mathrm{P}, \mathrm{Mg}$, and $\mathrm{Ca}$ concentrations were found between the two groups; however, differences were not found for $K$. The resistant-group accessions maintained higher concentrations of $\mathrm{Mg}$ and $\mathrm{Ca}$ than the sensitive group.
\end{abstract}

Soil acidity is a major problem in establishment and maintenance of turfgrass in many areas of the world (Foy and Murray, 1978). Aluminum (Al) toxicity has been identified as a major problem for crop production in acidic soils since 1918 (Hartwell and Pember, 1918). At soil $\mathrm{pH}$ of 5 or less, toxic forms of $\mathrm{Al}$ become soluble in the soil solution, inhibiting root growth and function and thus affecting plant growth (Kochian et al., 2005). Negative effects of $\mathrm{Al}$ on uptake of calcium $(\mathrm{Ca})$, magnesium $(\mathrm{Mg})$, and phosphorus $(\mathrm{P})$ have been demonstrated in plant species, including maize (Zea mays L.) (Keltjens, 1995), sorghum (Sorghum bicolor L.) (Tan and Keltjens, 1990), and rice (Oriza sativa L.) (Jan,1991). Marschner (1991) and others (Foy and Murray, 1978) demonstrated that grasses in acidic soils suffered from $\mathrm{P}$,

Received for publication 12 Dec. 2008. Accepted for publication 16 Feb. 2009.

${ }^{1}$ To whom reprint requests should be addressed; e-mail turfunit@yahoo.com.cn; haibol@clemson.edu. grass is well adapted to acid soils, but it also can live in slightly neutral soils and coastal areas with soil $\mathrm{pH}$ greater than 7 . Johnson and Carrow (1992) found that centipedegrass growth was better in $\mathrm{pH} 6.7$ than in $\mathrm{pH} 5.1$ when the soil was poorly fertilized. Baldwin et al. (2005) reported the Al effect on growth and nutrient uptake of 10 warm-season turfgrass species, including centipedegrass, and found that growth and nutrient absorption of most turfgrasses were inhibited when $\mathrm{Al}$ concentrations were greater than $640 \mu \mathrm{M}$. Among the 10 warm-season turfgrasses studied, carpetgrass (Axonopus affinis Chase) was the most Al-resistant species and centipedegrass exhibited moderate $\mathrm{Al}$ resistance. However, a lack of information remains about $\mathrm{Al}$ tolerance among centipedegrass accessions or cultivars to demonstrate the genetic diversity in acid soil adaptation. Therefore, the objectives of this study were 1) to conduct a preliminary evaluation of relative aluminum tolerance of 48 centipedegrass accessions plus TifBlair centipedegrass and a common centipedegrass from the United States by using a culture solution method; and 2) to determine $\mathrm{Al}$ effects on nutrient uptake between resistant-group and sensitive-group accessions among the 50 accessions and cultivars screened.

\section{Materials and Methods}

Aluminum solution screening experiment. A total of 48 representative native accessions collected from 13 provinces in the Yangtze River Valley in China (Fig. 1) plus TifBlair centipedegrass and a common centipedegrass developed in the United States were used in this experiment. All accessions were collected by Dr. Jianxiu Liu from 1998 to 2001 and cultured at the Turfgrass Plots of Nanjing Botanical Garden Mem. Sun Yat-Set. The experiments were conducted under greenhouse conditions in Nanjing Botanical Garden Mem. Sun Yat-Set, Nanjing, Jiangsu Province, China. The greenhouse was maintained at 33 to $37^{\circ} \mathrm{C}$ during the day and 25 to $28{ }^{\circ} \mathrm{C}$ at night with $90 \%$ natural sunlight and a relative humidity range of $48 \%$ to $69 \%$ during the study.

To have enough young seedlings for the experiments and a uniformity control, a preexperimental culture was conducted. Pieces of stolons with only one bud with similar length between 5 to $6 \mathrm{~cm}$ were used. In each $250-\mathrm{mL}$ plastic cup $(6.5 \mathrm{~cm}$ in diameter, 9.5 $\mathrm{cm}$ in height) filled with quartz grits with multiple pinholes at the bottom, four similar pieces of the previously described stolons were planted. A total of 100 pieces of stolons of each accession or cultivar were planted into 25 cups, and then the cups were suspended on a foam rack, which had 54 holes cut and held as many as 54 cups. The foam racks with cups were placed on top of large containers filled with $40 \mathrm{~L}$ modified halfstrength Hoagland nutrient solution (Hoagland and Arnon, 1956) with the following nutrient concentrations (in $\mathrm{mM}$ ): $2.5 \mathrm{Ca}\left(\mathrm{NO}_{3}\right)_{2}, 2.5$ $\mathrm{KNO}_{3}, 1 \mathrm{MgSO}_{4}$, and $0.5 \mathrm{NH}_{4} \mathrm{H}_{2} \mathrm{PO}_{4}$; and (in 


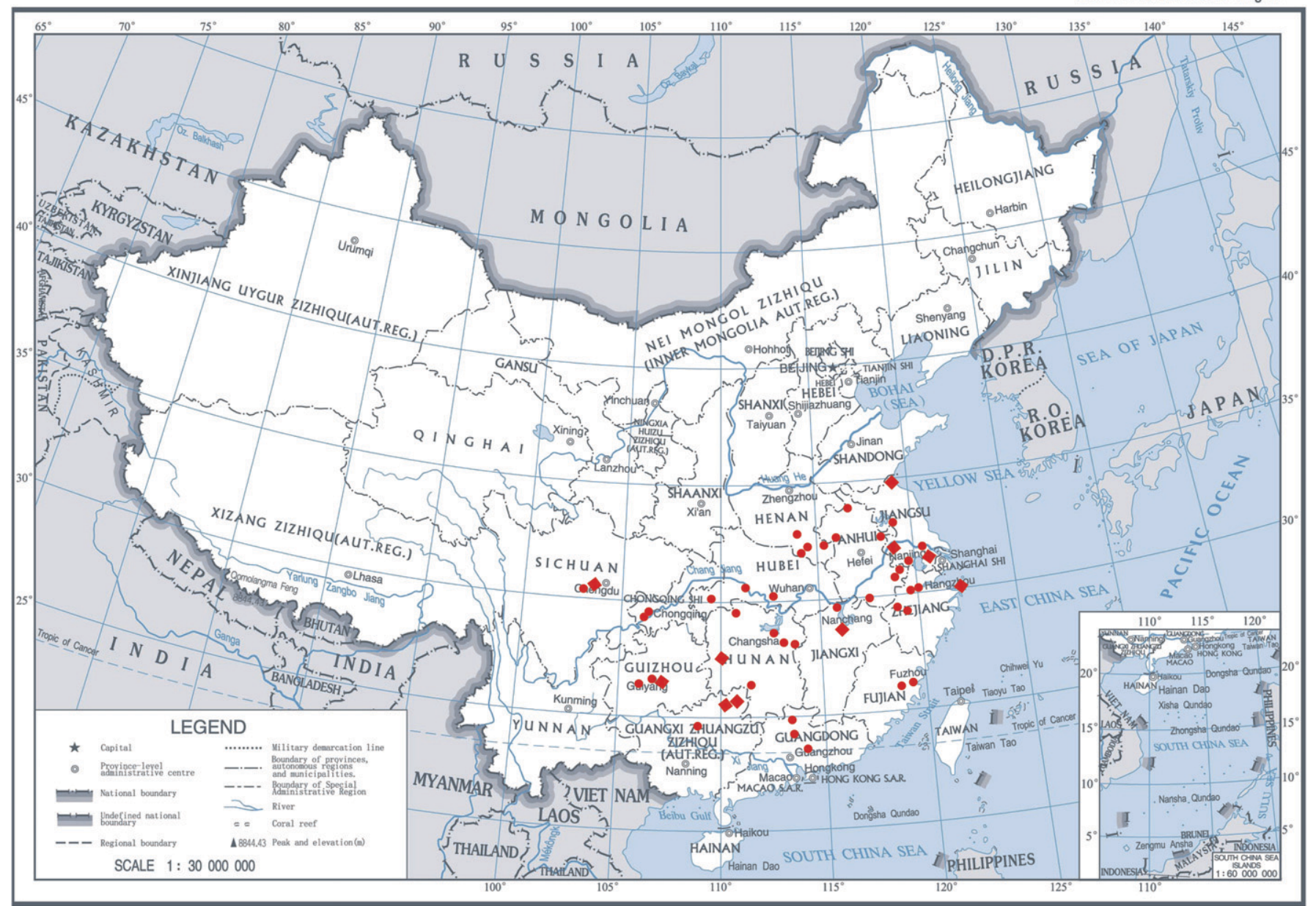

GS (2008) 1415 号

Jun. 2008 Produced by State Bureau of Surveying and Mapping

Fig. 1. The 48 collection locations of the tested centipedegrass accessions. The 10 centipdedgrass accessions used for acid soil nutrition uptake analyses.

$\mu \mathrm{M})$ : 46 boron $(\mathrm{B}), 0.3$ copper $(\mathrm{Cu}), 0.1$ molybdenum (Mo), 9.2 manganese $(\mathrm{Mn})$, 0.8 zinc $(\mathrm{Zn})$, and 50 iron (Fe)-EDTA aerated continuously by using an aerating pump and was changed weekly. All plant materials were pre-experimentally cultured for 2 weeks under the greenhouse conditions described.

After 2 weeks of pre-experimental culture, similar shoot and root size plants (four to five fully open leaves and 5 to $6 \mathrm{~cm}$ root) were transplanted into new cups of similar sizes and materials filled in as described earlier for the preliminary solution screening experiment. Three similar individual plants of each accession or cultivar were transplanted into one cup. To avoid and minimize possible contaminations of root exudates between different accessions or cultivars (Ma et al., 1997), three cups of the same accession or cultivar were suspended on one foam board cut with three holes, which was put on the top of a $2.5-\mathrm{L}$ pot $(17 \mathrm{~cm}$ in diameter, $15 \mathrm{~cm}$ in height) filled with $2 \mathrm{~L}$ culture solution with the following nutrient concentrations (in $\mathrm{mM}$ ): $1.25 \mathrm{Ca}\left(\mathrm{NO}_{3}\right)_{2}, 1.25$ $\mathrm{KNO}_{3}, 0.5 \mathrm{MgSO}_{4}$, and $0.025 \mathrm{NH}_{4} \mathrm{H}_{2} \mathrm{PO}_{4}$; and (in $\mu \mathrm{M}$ ): $46 \mathrm{~B}, 0.3 \mathrm{Cu}, 0.1 \mathrm{Mo}, 9.2 \mathrm{Mn}, 0.8$ $\mathrm{Zn}$, and $28 \mathrm{Fe}$-EDTA. An Al concentration of $1500 \mu \mathrm{M}$ used for this study was determined based on findings by Baldwin et al. (2005) on 10 warm-season turfgrasses using a $1440 \mu \mathrm{M}$ Al solution culture for 1 month with relative root mass and relative shoot mass reductions of $34 \%$ and $28 \%$, respectively, for centipedegrass. As a result of the large number of centipedegrass accessions used in this study, which were distributed among areas from $19^{\circ} 01^{\prime}$ to $35^{\circ} 01^{\prime}$ north latitude in China (Liu and He, 1998) plus two U.S. centipedegrasses, only a control and $1500 \mu \mathrm{M} \mathrm{Al}$ $\left(\mathrm{AlCl}_{3} \cdot 6 \mathrm{H}_{2} \mathrm{O}\right)$ were used. The $\mathrm{pH}$ of nutrient solutions of both concentrations was adjusted daily to $4.0 \pm 0.2(\mathrm{HCl}$ or $\mathrm{NaOH})$ and measured by using a portable $\mathrm{pH}$ meter (JENCO 6010; INC Technical Incorporated, Cincinnati, OH). All solutions were aerated continuously by using an aerating pump and solutions were changed every $3 \mathrm{~d}$. All the nutrient solution was prepared with $\mathrm{DD}_{2} \mathrm{O}$ and the duration of treatment lasted $28 \mathrm{~d}$. All the screened accessions and cultivars were arranged as a randomized complete block design with three replications.

An acid soil culture experiment with 10 selected accessions. The 10 accessions used for evaluation difference in nutrition uptake were planted in acid subsoil for confirming the results by culture solution method in the greenhouse mentioned. The acid subsoil, collected from Red Soil Ecological Experiment Station of Chinese Academy of Sciences, has a pH of 4.5 (ratio of soil to water is $1: 1$ and $\mathrm{KCl}$-extractable $\mathrm{Al}$ is $11.6 \mathrm{cmol} \cdot \mathrm{kg}^{-1}$ ), $0.27 \%$ organic matter, $0.056 \%$ total nitrogen, $5.41 \mathrm{mg} \cdot \mathrm{kg}^{-1}$ available $\mathrm{P}$, and $54.41 \mathrm{mg} \cdot \mathrm{kg}^{-1}$ available $\mathrm{K}$. The acid subsoil was air-dried and put into the pot $(16 \mathrm{~cm}$ in diameter, $12 \mathrm{~cm}$ in height), and each pot contained $1000 \mathrm{~g}$ acid subsoil. The acid subsoil was treated with $\mathrm{CaCO}_{3}$ to adjust its $\mathrm{pH}$ to 5.8 and used as a control. Fertilization with $\mathrm{NH}_{4} \mathrm{NO}_{3}$ and $\mathrm{KH}_{2} \mathrm{PO}_{4}$ added $\mathrm{N}, \mathrm{P}$, and $\mathrm{K}$ at 100,109 , and $137 \mathrm{mg} \cdot \mathrm{kg}^{-1}$ of the soil, respectively, for both limed and nonlimed soils. The 10 accession stolons with one bud on each piece of stolon were uniformly planted in each pot. Each accession was repeated in three pots. After 1 week of growth, six stolon pieces with the similar size and appearance were retained in each pot and grown for $28 \mathrm{~d}$.

The relative dry shoot mass (RSW), relative dry root mass (RRW), and relative dry total biomass (RTW) in acid subsoil were obtained and calculated in the same method as in culture solution method mentioned 
previously taking one pot as a replication. All pots were arranged in a randomized complete block design with three replications.

Date collection and analyses. After 28 $\mathrm{d}$ of $\mathrm{Al}$ treatment, roots and shoots were separated and washed with deionized water to remove any residual soil or nutrients and then oven-dried at $80{ }^{\circ} \mathrm{C}$ for $48 \mathrm{~h}$ and weighed. The dried roots and shoots were used for nutrient uptake analyses by determining the individual nutrient concentrations. The RSW, RRW, and RTW were calculated using the following formulas, respectively: (dry root or shoot mass in one cup with $\mathrm{Al} /$ dry root or shoot mass in one cup without $\mathrm{Al}) \times 100 \%$ (dry root + shoot mass in one cup with $\mathrm{Al} / \mathrm{dry}$ root + shoot in one cup without $\mathrm{Al}) \times 100 \%$. All relative values were based on the controls.

Values of the relative growth parameters (RSM, RRM, RTM) were submitted to analysis of variance procedures and parameters. Means were separated using Duncan's multiple range test $(\alpha=0.05)$. As a result of the difficulty in handling all 50 accessions and cultivars for nutrient uptake analyses, only five most Al-resistant and five most Alsensitive accessions were artificially chosen for comparing differences in plant uptake of $\mathrm{Al}, \mathrm{P}, \mathrm{Mg}, \mathrm{Ca}$, and $\mathrm{K}$ when exposed to $\mathrm{Al}$ based on the list provided in Table 1. For individual nutrient concentration analyses, the dry shoots and roots of the chosen accessions were ground. From the ground material, $0.2 \mathrm{~g}$ was weighed and placed into a $100-\mathrm{mL}$ tube and digested with $5 \mathrm{~mL} 87 \%$ $\mathrm{HNO}_{3}+13 \% \mathrm{HClO}_{4}$ for $12 \mathrm{~h}$, and then the digestion tubes were heated in a sequential procedure $\left(80^{\circ} \mathrm{C} 40 \mathrm{~min}, 100^{\circ} \mathrm{C} 60 \mathrm{~min}, 120\right.$ ${ }^{\circ} \mathrm{C} 80 \mathrm{~min}, 140{ }^{\circ} \mathrm{C} 100 \mathrm{~min}, 160^{\circ} \mathrm{C} 120 \mathrm{~min}$, and $180{ }^{\circ} \mathrm{C}$ until the samples were totally dried). The samples were then removed from the digestion tube by adding $50 \mathrm{~mL} 5 \%$ $\mathrm{HNO}_{3}$ and shaken vigorously. The concentrations of $\mathrm{P}, \mathrm{Mg}, \mathrm{Ca}, \mathrm{K}$, and $\mathrm{Al}$ of the sample solutions were analyzed by ICP-AES (Zhao et al., 1994). The relative concentrations of $P$, $\mathrm{Mg}, \mathrm{Ca}, \mathrm{K}$, and $\mathrm{Al}$ were calculated using the

Table 1. Relative root mass, shoot mass, total biomass of 50 accessions and cultivars treated with or without aluminum $(0$ or $1500 \mu \mathrm{M}$ at pH 4.0$)$ in culture solution for $28 \mathrm{~d}$.

\begin{tabular}{|c|c|c|c|c|c|c|}
\hline Accession & Collecting site & Latitude & Longitude & Relative root mass $(\%)$ & Relative shoot mass $(\%)$ & Relative total biomass (\%) \\
\hline E041 & Lingchuan Guangxi & $25^{\circ} 28^{\prime}$ & $110^{\circ} 17^{\prime}$ & $107.7 \mathrm{a}^{\mathrm{z}}$ & $78.5 \mathrm{a}$ & $80.5 \mathrm{a}$ \\
\hline E014 & Nanchang Jiangxi & $28^{\circ} 42^{\prime}$ & $119^{\circ} 54^{\prime}$ & $97.2 \mathrm{~b}$ & $72.3 \mathrm{ab}$ & $74.1 \mathrm{ab}$ \\
\hline E136 & Longli Guizhou & $26^{\circ} 27^{\prime}$ & $107^{\circ} 01^{\prime}$ & $93.7 \mathrm{~b}$ & $62.5 \mathrm{a}-\mathrm{f}$ & $67.4 \mathrm{a}-\mathrm{e}$ \\
\hline E072 & Guilin Guangxi & $25^{\circ} 18^{\prime}$ & $110^{\circ} 16^{\prime}$ & 89.7 bc & $66.7 \mathrm{a}-\mathrm{d}$ & $68.8 \mathrm{a}-\mathrm{d}$ \\
\hline E076 & Huahui Hunan & $27^{\circ} 31^{\prime}$ & $110^{\circ} 03^{\prime}$ & $87.6 \mathrm{bcd}$ & $72.1 \mathrm{abc}$ & $73.2 \mathrm{abc}$ \\
\hline E007 & Fuzhou Fujian & $26^{\circ} 05^{\prime}$ & $119^{\circ} 06^{\prime}$ & 83.0 cde & $53.1 \mathrm{~b}-\mathrm{h}$ & $56.2 \mathrm{~b}-\mathrm{j}$ \\
\hline E077 & Zhangjiajie Hunan & $29^{\circ} 16^{\prime}$ & $110^{\circ} 12^{\prime}$ & $79.6 \mathrm{def}$ & $64.0 \mathrm{a}-\mathrm{e}$ & $65.5 \mathrm{a}-\mathrm{f}$ \\
\hline E180 & Lanxi zhejiang & $29^{\circ} 31^{\prime}$ & $119^{\circ} 30^{\prime}$ & $79.3 \mathrm{def}$ & $48.6 \mathrm{~d}-\mathrm{i}$ & $50.4 \mathrm{~d}-\mathrm{k}$ \\
\hline E137 & Guiyang Guizhou & $26^{\circ} 35^{\prime}$ & $106^{\circ} 37^{\prime}$ & $77.8 \mathrm{~d}-\mathrm{g}$ & $53.4 \mathrm{~b}-\mathrm{h}$ & $55.0 \mathrm{c}-\mathrm{j}$ \\
\hline E117 & Boluo Guangdong & $23^{\circ} 21^{\prime}$ & $114^{\circ} 18^{\prime}$ & $74.9 \mathrm{e}-\mathrm{h}$ & $58.0 \mathrm{~b}-\mathrm{g}$ & $59.0 \mathrm{~b}-\mathrm{h}$ \\
\hline E131 & Yiyang Hunan & $28^{\circ} 24^{\prime}$ & $112^{\circ} 27^{\prime}$ & $74.4 \mathrm{e}-\mathrm{i}$ & $52.3 \mathrm{~b}-\mathrm{i}$ & $53.9 \mathrm{~d}-\mathrm{j}$ \\
\hline E129 & Ningxiang Hunan & $28^{\circ} 14^{\prime}$ & $112^{\circ} 36^{\prime}$ & $72.9 \mathrm{e}-\mathrm{j}$ & $52.4 \mathrm{~b}-\mathrm{i}$ & $53.7 \mathrm{~d}-\mathrm{j}$ \\
\hline E035 & Chuxian Anhui & $32^{\circ} 18^{\prime}$ & $118^{\circ} 20^{\prime}$ & $72.1 \mathrm{f}-\mathrm{k}$ & $58.3 \mathrm{~b}-\mathrm{g}$ & $59.5 \mathrm{~b}-\mathrm{g}$ \\
\hline E071 & Liuzhou Guangxi & $24^{\circ} 18^{\prime}$ & $109^{\circ} 26^{\prime}$ & $71.2 \mathrm{f}-1$ & $50.1 \mathrm{~d}-\mathrm{i}$ & $52.3 \mathrm{~d}-\mathrm{j}$ \\
\hline E039 & Lushan Jiangxi & $28^{\circ} 36^{\prime}$ & $116^{\circ} 00^{\prime}$ & $71.0 \mathrm{f}-1$ & $56.9 \mathrm{~b}-\mathrm{h}$ & $57.8 \mathrm{~b}-\mathrm{i}$ \\
\hline E158 & 'TifBlair' & - & - & $69.0 \mathrm{f}-\mathrm{m}$ & $52.6 \mathrm{~b}-\mathrm{i}$ & $53.7 \mathrm{~d}-\mathrm{j}$ \\
\hline E140 & Qionglai Sichuan & $30^{\circ} 24^{\prime}$ & $103^{\circ} 41^{\prime}$ & $68.9 \mathrm{f}-\mathrm{m}$ & $51.9 \mathrm{~b}-\mathrm{i}$ & $53.3 \mathrm{~d}-\mathrm{j}$ \\
\hline E062 & Fuyuan Guangdong & $24^{\circ} 58^{\prime}$ & $113^{\circ} 15^{\prime}$ & $68.5 \mathrm{f}-\mathrm{m}$ & $51.0 \mathrm{c}-\mathrm{i}$ & $52.2 \mathrm{~d}-\mathrm{j}$ \\
\hline E079 & Shien Hubei & $30^{\circ} 15^{\prime}$ & $109^{\circ} 22^{\prime}$ & $67.9 \mathrm{~g}-\mathrm{m}$ & $50.9 \mathrm{c}-\mathrm{i}$ & $52.6 \mathrm{~d}-\mathrm{j}$ \\
\hline E157 & Common & - & - & $67.7 \mathrm{~g}-\mathrm{m}$ & $50.8 \mathrm{c}-\mathrm{i}$ & $52.3 \mathrm{~d}-\mathrm{j}$ \\
\hline E084 & Anshun Guizhou & $26^{\circ} 14^{\prime}$ & $105^{\circ} 54^{\prime}$ & $67.4 \mathrm{~g}-\mathrm{m}$ & $50.2 \mathrm{~d}-\mathrm{i}$ & $51.7 \mathrm{~d}-\mathrm{j}$ \\
\hline E013 & Yongtai Fujian & $25^{\circ} 50^{\prime}$ & $119^{\circ} 06^{\prime}$ & $67.3 \mathrm{~g}-\mathrm{n}$ & $51.4 \mathrm{~b}-\mathrm{i}$ & $52.5 \mathrm{~d}-\mathrm{j}$ \\
\hline E022 & Wuxi Jiangsu & $31^{\circ} 35^{\prime}$ & $120^{\circ} 20^{\prime}$ & $66.1 \mathrm{~h}-\mathrm{O}$ & $47.7 \mathrm{~d}-\mathrm{i}$ & $48.8 \mathrm{~d}-\mathrm{k}$ \\
\hline E126 & Changsha Hunan & $28^{\circ} 10^{\prime}$ & $112^{\circ} 49^{\prime}$ & $65.6 \mathrm{~h}-\mathrm{p}$ & $49.8 \mathrm{~d}-\mathrm{i}$ & $51.3 \mathrm{~d}-\mathrm{k}$ \\
\hline E074 & Yongzhou Hunan & $26^{\circ} 16^{\prime}$ & $111^{\circ} 37^{\prime}$ & $65.3 \mathrm{~h}-\mathrm{p}$ & $54.7 \mathrm{~b}-\mathrm{h}$ & $55.7 \mathrm{~b}-\mathrm{j}$ \\
\hline E064 & Yingde Guangdong & $24^{\circ} 06^{\prime}$ & $113^{\circ} 30^{\prime}$ & $64.3 \mathrm{~h}-\mathrm{p}$ & $46.5 \mathrm{~d}-\mathrm{i}$ & $47.8 \mathrm{e}-\mathrm{k}$ \\
\hline E030 & Ningguo Anhui & $30^{\circ} 08^{\prime}$ & $119^{\circ} 00^{\prime}$ & $63.8 \mathrm{~h}-\mathrm{p}$ & $49.9 \mathrm{~d}-\mathrm{i}$ & $50.8 \mathrm{~d}-\mathrm{k}$ \\
\hline E189 & Guangde Anhui & $30^{\circ} 52^{\prime}$ & $119^{\circ} 32^{\prime}$ & $63.3 \mathrm{i}-\mathrm{q}$ & $47.7 \mathrm{~d}-\mathrm{i}$ & $48.9 \mathrm{~d}-\mathrm{k}$ \\
\hline E152 & Luoshan Henan & $32^{\circ} 11^{\prime}$ & $114^{\circ} 33^{\prime}$ & $62.9 \mathrm{j}-\mathrm{q}$ & $47.8 \mathrm{~d}-\mathrm{i}$ & $49.0 \mathrm{~d}-\mathrm{k}$ \\
\hline E078 & Yichang Hubei & $30^{\circ} 35^{\prime}$ & $111^{\circ} 00^{\prime}$ & $61.2 \mathrm{k}-\mathrm{q}$ & $47.1 \mathrm{~d}-\mathrm{i}$ & $48.2 \mathrm{e}-\mathrm{k}$ \\
\hline E033 & Tunxi Anhui & $29^{\circ} 43^{\prime}$ & $118^{\circ} 20^{\prime}$ & $61.2 \mathrm{k}-\mathrm{q}$ & $41.4 \mathrm{f}-\mathrm{i}$ & $42.9 \mathrm{~g}-\mathrm{k}$ \\
\hline E051 & Yixing Jiangsu & $31^{\circ} 22^{\prime}$ & $119^{\circ} 49^{\prime}$ & $59.81-\mathrm{r}$ & $46.6 \mathrm{~d}-\mathrm{i}$ & $47.8 \mathrm{e}-\mathrm{k}$ \\
\hline E151 & Xinyang Henan & $31^{\circ} 50^{\prime}$ & $114^{\circ} 04^{\prime}$ & $59.51-\mathrm{r}$ & $45.9 \mathrm{~d}-\mathrm{i}$ & $46.8 \mathrm{f}-\mathrm{k}$ \\
\hline E121 & Chuzhou Anhui & $32^{\circ} 22^{\prime}$ & $118^{\circ} 06^{\prime}$ & $59.0 \mathrm{~m}-\mathrm{r}$ & $46.5 \mathrm{~d}-\mathrm{i}$ & $47.5 \mathrm{e}-\mathrm{k}$ \\
\hline E090 & Nanshan Park Chongqing & $29^{\circ} 32^{\prime}$ & $106^{\circ} 33^{\prime}$ & $58.3 \mathrm{~m}-\mathrm{s}$ & $44.1 \mathrm{e}-\mathrm{i}$ & $45.7 \mathrm{f}-\mathrm{k}$ \\
\hline E021 & Hangzhou Zhejiang & $30^{\circ} 20^{\prime}$ & $119^{\circ} 54^{\prime}$ & $57.7 \mathrm{~m}-\mathrm{t}$ & $45.5 \mathrm{~d}-\mathrm{i}$ & $46.5 \mathrm{f}-\mathrm{k}$ \\
\hline E092-1 & Yubei Chongqing & $29^{\circ} 32^{\prime}$ & $106^{\circ} 33^{\prime}$ & $56.0 \mathrm{n}-\mathrm{t}$ & $44.9 \mathrm{~d}-\mathrm{i}$ & $45.7 \mathrm{f}-\mathrm{k}$ \\
\hline E185 & Fuyang Zhejiang & $30^{\circ} 20^{\prime}$ & $119^{\circ} 54^{\prime}$ & $55.6 \mathrm{o}-\mathrm{t}$ & $45.7 \mathrm{~d}-\mathrm{i}$ & $46.5 \mathrm{f}-\mathrm{k}$ \\
\hline E142 & Huoqiu Anhui & $31^{\circ} 45^{\prime}$ & $116^{\circ} 06^{\prime}$ & $54.6 \mathrm{p}-\mathrm{t}$ & $37.3 \mathrm{ghi}$ & $38.3 \mathrm{ijk}$ \\
\hline E107 & Queshan Henan & $32^{\circ} 43^{\prime}$ & $113^{\circ} 59^{\prime}$ & $52.4 \mathrm{q}-\mathrm{u}$ & $44.9 \mathrm{~d}-\mathrm{i}$ & $45.5 \mathrm{f}-\mathrm{k}$ \\
\hline E143 & Gushi Henan & $32^{\circ} 10^{\prime}$ & $115^{\circ} 37^{\prime}$ & $49.8 \mathrm{r}-\mathrm{u}$ & $45.1 \mathrm{~d}-\mathrm{i}$ & $45.5 \mathrm{f}-\mathrm{k}$ \\
\hline E016 & Jinhua Zhejiang & $29^{\circ} 07^{\prime}$ & $119^{\circ} 32^{\prime}$ & $49.6 \mathrm{r}-\mathrm{u}$ & $43.3 \mathrm{e}-\mathrm{i}$ & $43.7 \mathrm{~g}-\mathrm{k}$ \\
\hline E109 & Xuyu Jiangsu & $32^{\circ} 56^{\prime}$ & $118^{\circ} 46^{\prime}$ & $49.1 \mathrm{r}-\mathrm{V}$ & $40.8 \mathrm{f}-\mathrm{i}$ & $41.3 \mathrm{~g}-\mathrm{k}$ \\
\hline E156 & Lianyunguang Jiangsu & $34^{\circ} 44^{\prime}$ & $119^{\circ} 21^{\prime}$ & $47.8 \mathrm{~s}-\mathrm{v}$ & $40.1 \mathrm{ghi}$ & $40.7 \mathrm{~g}-\mathrm{k}$ \\
\hline E080 & Qianjiang Hubei & $30^{\circ} 27^{\prime}$ & $112^{\circ} 48^{\prime}$ & $47.3 \mathrm{~s}-\mathrm{V}$ & $36.7 \mathrm{ghi}$ & $37.6 \mathrm{ijk}$ \\
\hline E046 & Suzhou Jiangsu & $31^{\circ} 16^{\prime}$ & $120^{\circ} 34^{\prime}$ & $46.7 \mathrm{t}-\mathrm{w}$ & $35.7 \mathrm{hi}$ & $36.6 \mathrm{jk}$ \\
\hline E027 & Lianyunguang Jiangsu & $34^{\circ} 36^{\prime}$ & $119^{\circ} 12^{\prime}$ & $43.6 \mathrm{uvw}$ & $42.2 \mathrm{e}-\mathrm{i}$ & $42.3 \mathrm{~g}-\mathrm{k}$ \\
\hline E184 & Putoshan Zhejiang & $30^{\circ} 01^{\prime}$ & $122^{\circ} 30^{\prime}$ & $42.2 \mathrm{uvw}$ & $38.6 \mathrm{ghi}$ & $39.0 \mathrm{~h}-\mathrm{k}$ \\
\hline E089 & Xinjin Sichuan & $30^{\circ} 14^{\prime}$ & $103^{\circ} 48^{\prime}$ & $38.6 \mathrm{vw}$ & $39.7 \mathrm{ghi}$ & $39.6 \mathrm{~g}-\mathrm{k}$ \\
\hline E006 & Nanjing Jiangsu & $32^{\circ} 03^{\prime}$ & $118^{\circ} 52^{\prime}$ & $36.6 \mathrm{w}$ & $30.9 \mathrm{i}$ & $31.5 \mathrm{k}$ \\
\hline \multicolumn{4}{|c|}{ Range of variation $(\%)$} & $36.6-107.7$ & $30.9-78.5$ & $0.531-80.5$ \\
\hline \multicolumn{4}{|c|}{$\mathrm{CV}(\%)$} & 39.9 & 32.9 & 33.6 \\
\hline \multicolumn{4}{|c|}{ F value } & $20.31 * * y$ & $2.63 * *$ & $3.31^{* *}$ \\
\hline
\end{tabular}

${ }^{z}$ Values within a column followed by the same letter are not different at the $5 \%$ level of probability based on Duncan's multiple range test.

$\mathrm{y} * P<0.05$ significant difference; $* * P<0.01$ significant difference; NS $=$ no significant difference. 
Table 2. Relative root mass, shoot mass, total biomass of five resistant accessions and five sensitive accessions grown in acid subsoil for $28 \mathrm{~d}$.

\begin{tabular}{lccc}
\hline Accessions & Relative root mass (\%) & Relative shoot mass (\%) & Relative total biomass (\%) \\
\hline E041 & $82.0 \mathrm{c}^{\mathrm{z}}$ & $85.5 \mathrm{ef}$ & $84.4 \mathrm{e}$ \\
E014 & $77.5 \mathrm{bc}$ & $80.5 \mathrm{ef}$ & $79.8 \mathrm{de}$ \\
E136 & $66.4 \mathrm{~b}$ & $86.3 \mathrm{f}$ & $79.2 \mathrm{de}$ \\
E072 & $67.8 \mathrm{~b}$ & $67.9 \mathrm{~cd}$ & $67.9 \mathrm{c}$ \\
E076 & $68.7 \mathrm{~b}$ & $74.0 \mathrm{de}$ & $72.3 \mathrm{~cd}$ \\
E046 & $47.9 \mathrm{a}$ & $49.6 \mathrm{ab}$ & $49.0 \mathrm{ab}$ \\
E027 & $45.4 \mathrm{a}$ & $62.0 \mathrm{c}$ & $56.4 \mathrm{~b}$ \\
E184 & $45.6 \mathrm{a}$ & $48.5 \mathrm{ab}$ & $47.7 \mathrm{ab}$ \\
E089 & $51.1 \mathrm{a}$ & $56.8 \mathrm{bc}$ & $54.9 \mathrm{~b}$ \\
E006 & $41.4 \mathrm{a}$ & $44.1 \mathrm{a}$ & $43.5 \mathrm{a}$ \\
F value & $17.13^{* * y}$ & $17.74 * *$ & $22.69 * *$ \\
\hline
\end{tabular}

${ }^{z}$ Values within a column followed by the same letter are not different at the $5 \%$ level of probability based on Duncan's multiple range test.

$\mathrm{y} * P<0.05$ significant difference; $* * P<0.01$ significant difference; $\mathrm{NS}=$ no significant difference.

following formula: (concentrations of $\mathrm{P}, \mathrm{Mg}$, $\mathrm{Ca}, \mathrm{K}$, or $\mathrm{Al}$ in one cup with $\mathrm{Al} /$ concentrations of $\mathrm{P}, \mathrm{Mg}, \mathrm{Ca}, \mathrm{K}$, or $\mathrm{Al}$ in one cup without $\mathrm{Al}) \times 100 \%$. All statistical analyses were conducted by SPSS10.0 (SPSS10.0 Software in Medical Statistics, 2003).

\section{Results and Discussion}

Growth of the 50 centipedegrass accessions and cultivars studied was adversely affected when exposed to $1500 \mu \mathrm{M}$ Al for $28 \mathrm{~d}$ (Table 1). The root morphology and appearance were abnormal with coralloid branches and poor root hairs being observed. There were significant differences in RRW, RSW, and RTW among the 50 accessions and cultivars. The variation ranges of the RRW, RSW, and RTW were $36.6 \%$ to $107.7 \%$, $30.9 \%$ to $78.5 \%$, and $31.5 \%$ to $80.5 \%$ respectively, and the coefficients of variation were $39.9 \%, 32.9 \%$, and $33.6 \%$, respectively. Based on the results of RRW as the evaluation parameter, the accessions from China, E041, E014, E136, E072, E076, and E007, were more resistant than TifBlair and the common centipedegrass used in the study, whereas 14 accessions from China were more sensitive than TifBlair and the common centipedegrass. Based on the results of RSW, the Chinese accession E041 was more resistant than TifBlair and the common centipedegrass. Based on RTW, E041, E014, and E076 were more resistant than TifBlair and the common centipedegrass, whereas Chinese accession E006 was more sensitive than TifBlair and the common centipedegrass. According to the information referencing TifBlair registration (Hanna et al., 1997), TifBlair is an Al-tolerant cultivar. A greater genetic diversity in $\mathrm{Al}$ tolerance among the 48 screened accessions collected in China was identified through this research. The results indicate a promising potential for future enhancement of Al resistance among centipedegrass accessions and cultivars. The variation in Al tolerance among centipedegrass accessions from China were greater than expected, which could be partially explained by centipedegrass being a native grass in China and other Asian countries. It was observed that accessions showing less $\mathrm{Al}$ stress were from acid soil areas in China such as Guangxi, Jiangxi, and Guizhou Provinces where soil types are mainly lateritic red soils (Xiong and Kui, 1987). Other accessions showing more sensitivity to Al stresses were naturally distributed in slightly acid soil or neutral soil areas such as Jiangsu and Henan Provinces, in which soil types were mainly yellow-brown and Fluvo-aquic soils (Xiong and Kui, 1987). Liu et al. (1995) reported that the midwest ecotype Kentucky bluegrass ( $\mathrm{Poa}$ pratensis $\mathrm{L}$.) exhibited greater sensitivity to $\mathrm{Al}$ among seven ecotypes and could be attributable, in part, to these midwest habitats of origin where soil $\mathrm{pH}$ is typically near neutral.
The correlations among the RRW, RSW, and RTW were significant ( $r=0.699,0.803$, and 0.843 at $P<0.01$, respectively), so all three parameters could be used to evaluate the $\mathrm{Al}$ tolerance of centipedegrass accessions and cultivars, which is similar with several previous studies (Baldwin et al., 2005; Liu et al., 1995, 1996, 1997).

According to the results of the multiple comparisons in Table 1, the five accessions (E041, E014, E136, E072, and E076) more resistant to $\mathrm{Al}$ (resistant group) and five accessions (E006, E089, E184, E027, and E046) more sensitive to Al (sensitive group) were artificially chosen to determine the effect of Al on uptake of $\mathrm{P}, \mathrm{Mg}, \mathrm{Ca}, \mathrm{K}$, and $\mathrm{Al}$. The 10 accessions selected were grown in acid subsoil to evaluate the genetic diversity related to nutrient uptake under $\mathrm{Al}$ stress. There is a dearth of such information in the literature.

Significant differences were found between the resistant group and sensitive group of accessions when grown in acid subsoil for $28 \mathrm{~d}$ (Table 2). The resistant group of accessions demonstrated better growth than the sensitive-group accessions, which was consistent with results found earlier in the solution culture screening. However, $\mathrm{Al}$ had negative effects on uptake of $\mathrm{P}, \mathrm{Mg}, \mathrm{Ca}$, and $\mathrm{K}$ for both groups. The $\mathrm{Al}$ concentrations in shoots and roots of two groups were significantly higher than that of the control after Al treatment. A remarkable increase of 1.3 to 2.1 times in shoots and 7.0 to 15.2 times in roots (Table 3 ) indicates significant $\mathrm{Al}$ uptake among centipedegrasses. The results also indicate that $\mathrm{Al}$ is primarily retained in roots when absorbed by centipedegrasses with a relatively small amount being transported to shoots. The shoot Al concentrations of the five resistant-group accessions were significantly lower than the five sensitivegroup accessions, which agreed with previous reports that absorbed Al in crops and turfgrasses was transported to shoots slowly after being taken up by roots of resistant species or cultivars (Foy and Murray, 1998a; Kochian et al., 2005; Rengel and Robinson, 1989).

There was a significant negative effect of $\mathrm{Al}$ on $\mathrm{P}$ concentrations in shoots when exposed to $\mathrm{Al}$ for $28 \mathrm{~d}$. An average reduction

Table 3. The phosphorus $(\mathrm{P})$, magnesium $(\mathrm{Mg})$, calcium $(\mathrm{Ca})$, and potassium $(\mathrm{K})$ concentrations $(\mathrm{RT} /$ control \%) and aluminum $(\mathrm{Al})$ concentration $(\mathrm{RT} /$ control $)$ of resistant-group and sensitive-group accessions affected by $\mathrm{Al}$ at $1500 \mu \mathrm{M}$ in culture solutions for $28 \mathrm{~d}$.

\begin{tabular}{|c|c|c|c|c|c|c|c|c|c|c|}
\hline \multirow[b]{2}{*}{ Accession } & \multicolumn{2}{|c|}{$\mathrm{Al}$} & \multicolumn{2}{|c|}{$\mathrm{P}$} & \multicolumn{2}{|c|}{$\mathrm{Mg}$} & \multicolumn{2}{|c|}{$\mathrm{Ca}$} & \multicolumn{2}{|c|}{ K } \\
\hline & Shoot & Root & Shoot & Root & Shoot & Root & Shoot & Root & Shoot & Root \\
\hline E041(T)z & $1.27 \mathrm{a}^{\mathrm{y}}$ & $6.98 \mathrm{a}$ & $55.3 \mathrm{~b}^{\mathrm{y}}$ & 86.4 & $51.8 \mathrm{~cd}$ & 58.4 & $63.3 \mathrm{e}$ & $71.0 \mathrm{c}$ & 64.1 & 70.3 \\
\hline E014(T) & $1.48 \mathrm{ab}$ & $7.55 \mathrm{ab}$ & $52.4 \mathrm{~b}$ & 92.1 & $55.5 \mathrm{~d}$ & 51.7 & $60.5 \mathrm{e}$ & $63.2 \mathrm{bc}$ & 55.9 & 59.8 \\
\hline E136(T) & $1.39 \mathrm{ab}$ & $7.62 \mathrm{ab}$ & $50.0 \mathrm{~b}$ & 89.8 & 48.9 bcd & 49.5 & $56.2 \mathrm{de}$ & $60.6 \mathrm{abc}$ & 61.6 & 68.7 \\
\hline E072(T) & $1.30 \mathrm{ab}$ & $9.12 \mathrm{~b}$ & $52.8 \mathrm{~b}$ & 86.9 & $50.5 \mathrm{~cd}$ & 50.8 & $60.8 \mathrm{e}$ & $66.6 \mathrm{bc}$ & 57.7 & 63.8 \\
\hline E076(T) & $1.56 \mathrm{bc}$ & $8.07 \mathrm{ab}$ & $49.5 \mathrm{~b}$ & 93.3 & $47.9 \mathrm{bcd}$ & 48.5 & $56.9 \mathrm{de}$ & $55.2 \mathrm{ab}$ & 62.6 & 70.4 \\
\hline E006(S) & $2.06 \mathrm{e}$ & $15.18 \mathrm{~d}$ & $27.7 \mathrm{a}$ & 89.0 & $36.7 \mathrm{a}$ & 39.6 & $41.1 \mathrm{ab}$ & $52.1 \mathrm{ab}$ & 57.9 & 66.1 \\
\hline E089(S) & $2.09 \mathrm{e}$ & $14.98 \mathrm{~d}$ & $28.4 \mathrm{a}$ & 92.0 & $38.4 \mathrm{ab}$ & 41.0 & $39.3 \mathrm{a}$ & $50.8 \mathrm{ab}$ & 60.3 & 67.1 \\
\hline E184(S) & $1.74 \mathrm{~cd}$ & $13.69 \mathrm{~cd}$ & $31.8 \mathrm{a}$ & 95.6 & $41.5 \mathrm{abc}$ & 44.0 & $44.6 \mathrm{abc}$ & $52.0 \mathrm{ab}$ & 50.3 & 52.9 \\
\hline E027(S) & $1.82 \mathrm{cde}$ & $14.04 \mathrm{~cd}$ & $29.5 \mathrm{a}$ & 92.8 & $39.1 \mathrm{ab}$ & 49.9 & $47.1 \mathrm{bc}$ & $45.4 \mathrm{a}$ & 56.7 & 66.2 \\
\hline E046(S) & $1.85 \mathrm{de}$ & $12.39 \mathrm{c}$ & $30.1 \mathrm{a}$ & 95.4 & $41.2 \mathrm{abc}$ & 41.7 & $50.6 \mathrm{~cd}$ & $51.7 \mathrm{ab}$ & 59.5 & 71.2 \\
\hline Mean & 1.65 & 10.96 & 40.7 & 91.3 & 45.2 & 47.5 & 52.1 & 56.8 & 58.7 & 65.6 \\
\hline $\mathrm{F}$ value & $12.78 * * \mathrm{x}$ & $40.37 * *$ & $18.15^{* *}$ & NS & $3.68 * *$ & NS & $13.93 * *$ & $2.78 *$ & NS & NS \\
\hline
\end{tabular}

${ }^{\mathrm{z}} \mathrm{T}=$ resistant group; $\mathrm{S}=$ sensitive group.

${ }^{y}$ Values within a column followed by the same letter are not different at the $5 \%$ level of probability based on Duncan's multiple range test.

$\mathrm{x} * P<0.05$ significant difference; $* * P<0.01$ significant difference; $\mathrm{NS}=$ no significant difference. 
in $\mathrm{P}$ of $59.3 \%$ in shoots and $8.7 \%$ in roots was observed. The $\mathrm{P}$ concentration of the resistant group was significantly higher than the sensitive group (Table 3 ). The results indicate that there was less influence of $\mathrm{P}$ concentration in the resistant group compared with the sensitive group. Also, there was less influence of $\mathrm{P}$ in roots compared with shoots after Al treatment. Baldwin et al. (2005) reported that $\mathrm{Al}$ stress reduced both shoot and root $\mathrm{P}$ concentrations of centipedegrass and the results of this study also confirmed that conclusion. It was reported that formation of $\mathrm{P}-\mathrm{Al}$ complexes caused a reduction in root influx of $\mathrm{P}$ and transportation to shoots, consequently decreasing $\mathrm{P}$ accumulation in plant (Pfeffer et al., 1986). So, the assumption is that the formation of $\mathrm{P}-\mathrm{Al}$ complexes might occur in both resistant-group and sensitive-group accession roots. However, the higher P concentrations (RT/control \%) of the resistant group might be explained by mechanisms that ameliorate $\mathrm{Al}$ toxicity and reduce the formation of $\mathrm{P}-\mathrm{Al}$ complexes, consequently increasing the transport of $\mathrm{P}$ to shoots and improving use of $\mathrm{P}$ in roots. Organic acid and phenolic compounds can form complex Al compounds resulting in reduced Al toxicity (Kochian et al., 2005), but higher P concentrations (RT/control \%) of the sensitive group were found as well and this could be the result of the formation of complex $\mathrm{P}-\mathrm{Al}$ compounds. However, additional experiments are needed to further explore $\mathrm{P}$ and $\mathrm{Al}$ relationships among centipedegrass and other turfgrass species.

There was a remarkable negative effect of $\mathrm{Al}$ on $\mathrm{Mg}, \mathrm{Ca}$, and $\mathrm{K}$ concentrations in shoots and roots in the two groups with an average reduction of $54.8 \%, 47.9 \%$, and $41.3 \%$ in shoots and $52.5 \%, 43.2 \%$, and $34.4 \%$ in roots, respectively (Table 3 ). When plants are exposed to $\mathrm{Al}, \mathrm{Mg}$ and $\mathrm{Ca}$ uptake has been significantly inhibited (Marschner, 1995). Rengel and Robinson (1989) reported that Alresistant annual ryegrass (Lolium multiflorum Lam.) cultivars could maintain greater uptake of $\mathrm{Ca}$ and $\mathrm{Mg}$ than sensitive ryegrass cultivars. Eduardo and Willem (2005) observed the same phenomenon in maize. Our study agreed with these findings. There were some controversies about the Al effect on K. Gassmann and Schroeder (1994) reported that Al inhibited plant uptake of $\mathrm{K}$ and decreased $\mathrm{K}$ concentrations in shoots and roots, because $\mathrm{Al}$ was considered a cation channel inhibitor and could subsequently result in the deficiency of $\mathrm{K}$ in shoots. However, Rengel and Robinson (1989) found that the $\mathrm{K}$ concentrations increased after a lower dosage of Al stress treatment with annual ryegrass.
Further research is needed to evaluate centipedegrass accessions on acid soils, including turf quality, drought stress, low temperature stress, and other environmental stresses. It is also meaningful to study $\mathrm{Al}$ tolerance mechanisms of resistant-group accessions such as $\mathrm{P}$ and $\mathrm{Al}$ relationships, the function of root secretions, and intracellular resistance mechanisms. Furthermore, to improve overall turf quality and morphological characteristics such as leaf width, plant height, recuperative ability, and pest resistance among centipedegrass accessions and cultivars, the Al-resistant group should be evaluated under field conditions to identify potential for further enhancement of this economically important turfgrass species.

\section{Literature Cited}

Baldwin, C.M., H. Liu, L.B. McCarty, W.B. Bauerle, and J.E. Toler. 2005. Aluminum tolerance of warm-season turfgrasses. Inter. Turfgrass Soc. Res. J. 10:811-817.

Duncan, R.R. and L.M. Shuman. 1993. Acid soil stress response of zoysiagrass. Intl. Turfgrass Soc. Res. J. 7:805-811.

Eduardo, D.M. and G.K. Willem. 2005. Long-term effects of aluminum exposure on nutrient uptake by maize phenotypes differing in aluminum resistance. J. Plant Nutr. 28:323-333.

Foy, C.D. and J.J. Murray. 1978. Differential tolerance of turfgrass cultivars to an acid soil high in exchangeable aluminum. Agron. J. 70:769-774.

Foy, C.D. and J.J. Murray. 1998a. Responses of Kentucky bluegrass cultivars to excess aluminum in nutrient solutions. J. Plant Nutr. 21:1967-1983.

Foy, C.D. and J.J. Murray. 1998b. Developing aluminum tolerant tall fescue for acid soils. J. Plant Nutr. 21:1301-1325.

Gassmann, W. and J.I. Schroeder. 1994. Inwardrectifying $\mathrm{K}^{+}$channels in root hair of wheat. A mechanism for aluminum sensitive low-affinity $\mathrm{K}^{+}$uptake and membrane potential control. Plant Physiol. 105:1399-1408.

Hanna, W.W. 1995. Centipedegrass diversity and vulnerability. Crop Sci. 35:332-334.

Hanna, W.W., J. Dobson, R.R. Duncan, and D. Thompson. 1997. Registration of 'TifBlair' Centipedegrass. Crop Sci. 37:1017.

Hanna, W.W. and J. Liu. 2003. Centipedegrass, p. 287-293. In: Casler, M.D. and R.R. Duncan (eds.). Turfgrass biology, genetics, and breeding. John Wiley \& Sons, Inc., Hoboken, NJ.

Hartwell, B.L. and F.R. Pember. 1918. The presence of aluminum as a reason for the difference in the effect of so-called acid soil on barley and rye. Soil Sci. 6:259-279.

Hoagland, D.R. and D.I. Arnon. 1956. The waterculture methods for growing plants without soil. California Agr. Experiment Sta. Circular. p. 347.

James, E.H. and W.W. Hanna. 1994. Drought resistance in centipedegrass cultivars. HortScience 29:1528-1531.
Jan, F. 1991. Aluminum effects on growth, nutrient net uptake and transport in 3 rice (Oriza sativa L.) cultivars with different sensitivity to aluminum. Physiol. Plant. 83:441-448.

Johnson, B.J. and R.N. Carrow. 1992. Influence of soil $\mathrm{pH}$ and fertility programs on centipedegrass. Agron. J. 84:21-26.

Keltjens, W.G. 1995. Magnesium uptake by Alstressed maize plants with special emphasis on cation interactions at root exchange sites. Plant Soil 171:141-146.

Kochian, L.V., M.A. Piñeros, and O.A. Hoekenga. 2005. The physiology, genetics and molecular biology of plant aluminum resistance and toxicity. Plant Soil 274:175-195.

Liu, H. 2005. Aluminum resistance among seeded bermudagrasses. HortScience 40:221-223.

Liu, H., J.R. Heckman, and J.A. Murphy. 1995. Screening Kentucky bluegrass for aluminum tolerance. J. Plant Nutr. 18:1797-1814.

Liu, H., J.R. Heckman, and J.A. Murphy. 1996. Screening fine fescues for aluminum tolerance. J. Plant Nutr. 19:677-688.

Liu, H., J.R. Heckman, and J.A. Murphy. 1997. Greenhouse screening of turfgrasses for aluminum tolerance. Inter. Turfgrass Soc. Res. J. 8:719-728.

Liu, J.Y.L. and S. He. 1998. Species diversity of Chinese warm-season turfgrasses and the characteristic of geography distribution. Acta Agrestia Sinca. 6:45-52.

Ma, J.F., S.J. Zheng, S.F. Li, K. Takeda, and H. Matsumoto. 1997. A rapid hydroponic screening for aluminum tolerance in barley. Plant Soil 191:133-137.

Marschner, H. 1991. Mechanisms of adaptations of plants to acid soils. Plant Soil 134:1-20.

Marschner, H. 1995. Mineral nutrition of higher plants. 2nd Ed. Academic Press, New York, NY.

Pfeffer, P.E., S.I. Tu, W.V. Gerasimowicz, and J.R. Cavanaugh. 1986. In vivo ${ }^{32} \mathrm{P}$ NMR studies of corn root tissue and its uptake of toxic metal. Plant Physiol. 80:77-84.

Rengel, Z. and D.L. Robinson. 1989. Aluminum effects on growth and macronutrient uptake by annual ryegrass. Agron. J. 81:208-215.

SPSS10.0 Software in Medical Statistics. 2003. Guangdong Provincial Center for Disease Control and Prevention, Guangzhou, Guangdong, China.

Tan, K. and W.G. Keltjens. 1990. Effects of aluminum on growth, nutrient uptake, proton efflux and phosphorus assimilation of aluminum-tolerant and aluminum-sensitive sorghum (Sorghum bicolor) phenotypes, p. 397-401. In: van Beusichem, M.L. (ed.). Plant nutrition: Physiology and applications. Kluwer Academic Publishers, Dordrecht, The Netherlands.

Xiong, Y. and L. Kui. 1987. Chinese soil. Science Press, Beijing, China. p. 34-35 (in Chinese)

Zhao, F.J., S.P. McGrath, and A.R. Croslan. 1994 Comparison of three wet digestion methods for the determination of plant sulfur by inductively coupled plasma atomic emission spectrometry (ICP-AES). Commun. Soil Sci. Plant Anal. 25:407-418. 